\title{
Kepuasan Pelanggan Dan Pengaruhnya Pada Penurunan Penjualan PT Veranda Kencana
}

\author{
Herman Setyadji, Maria Marcella, Reonard Rico Effendi, Anindya \\ Pramura Wardani, Prasetya Aditya Imansyah
}

School of Business and Economics Universitas Prasetiya Mulya

JL. RA. Kartini (TB Simatupang), Cilandak Barat Jakarta Selatan, Jakarta 12430 Indonesia.

*. Corresponding Author: hermansetyadji@gmail.com

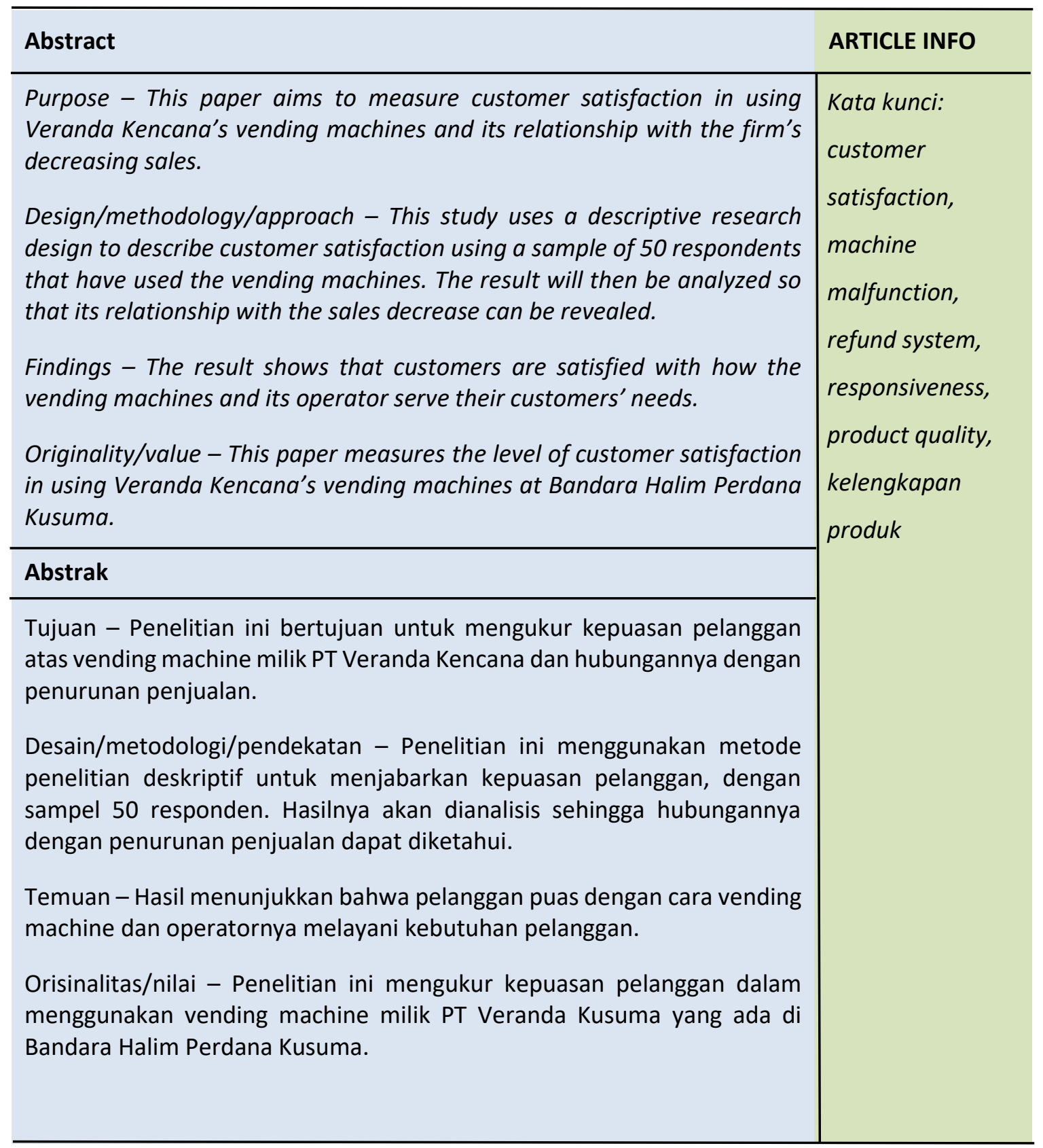


Vol.01, No. 2, 2018

\section{Pendahuluan}

Vending machine dapat didefinisikan sebagai alat yang dapat mengeluarkan produk untuk pelanggan secara otomatis tanpa operator (trendmesin.com). Vending machine sudah lama dikenal sebagai metode penyaluran makanan dan minuman yang mudah. Di kawasan Bandar Udara Halim Perdana Kusuma Jakarta, PT Veranda Kencana merupakan operator tunggal vending machine yang melayani konsumen.

Penelitian yang dilakukan oleh Grand View Research pada Desember tahun 2016 menyebutkan bahwa minuman kemasan diperkirakan menjadi segmen yang paling cepat berkembang di pasar industri vending machine. Di Amerika sendiri, industri vending machine diketahui memiliki tren positif. Namun, penelitian tersebut tidak tercermin pada PT Veranda Kencana Indonesia, yang diketahui mengalami penurunan penjualan atas minuman di vending machine Bandara Halim Perdana Kusuma, dari semula rata-rata 60 juta rupiah/bulan menjadi 30 juta rupiah/bulan.

Beberapa penelitian terdahulu menunjukkan bahwa customer satisfaction turut mempengaruhi sales performance. Customer satisfaction bahkan dipercaya berpotensi untuk meningkatkan penjualan (Rust et al., 1995; Gomez et al., 2004). Lee (2003) mengungkapkan beberapa variabel yang dapat menjadi parameter untuk mengukur customer satisfaction antara lain: machine malfunction, refund system, responsiveness, product quality, dan kelengkapan produk.

Oleh sebab itu, pernyataan yang ingin dijawab oleh peneliti adalah: Seberapa tinggi customer satisfaction dari PT Veranda Kencana saat ini terkait dengan machine malfunction, refund management, responsiveness to complaints, quality of items, dan kelengkapan produk? Penelitian ini bertujuan untuk membantu perusahaan mengetahui apakah ada permasalahan pada kepuasan pelanggan yang mengakibatkan penurunan penjualan. 
Vol.01, No. 2, 2018

\section{Tinjauan Pustaka}

Beberapa penelitian terdahulu menyimpulkan bahwa kepuasan pelanggan mempunyai pengaruh positif terhadap penjualan. Kepuasan pelanggan diartikan sebagai alat ukur untuk menentukan seberapa mampu suatu produk/layanan dalam memenuhi harapan pembeli. Oleh sebab itu, kepuasan pelanggan merupakan suatu poin penting yang dapat mempengaruhi pertumbuhan pasar (Iberahim et al., 2016). Akan tetapi, perlu diketahui bahwa kepuasan pelanggan atas kualitas suatu produk/layanan merupakan sesuatu yang subjektif (Shen, Tan, dan Xie 2000).

Untuk mengukur kepuasan dari pelanggan, Jones dan Sasser menggunakan 5-point likert scale dalam penelitiannya. Kelima poin ini terbagi ke dalam tiga level kepuasan; dissatisfied, satisfied, dan completely satisfied. Selanjutnya, Jones dan Sasser menganalisis adanya perbedaan yang signifikan terkait perilaku dari satisfied dan completely satisfied customers. Loyalitas dari masing-masing level kepuasan pelanggan dapat dilihat pada Gambar 3.1.

\section{Interpreting Levels of Satisfaction}
Response
Description
Loyalty
5
completely satisfied
very loyal
$3 \cdot 4$
setisfied
easily switched to a competitor
1.2
dissatisfied
very disloyal

\section{Gambar 2.1 Interpretation of Levels of Satisfaction \\ Jones dan Sasser (1995)}

Berdasarkan jurnal acuan yang ditulis oleh Lee (2003), terdapat beberapa variabel yang dapat menjadi parameter untuk mengukur kepuasan pelanggan atas layanan vending machine. Variabel-variabel tersebut yang akan dijelaskan pada 
bagian ini, antara lain: machine malfunction, refund system, responsiveness, product quality, dan kelengkapan produk.

\subsection{Machine malfunction}

Machine malfunction erat kaitannya dengan keandalan dari vending machine itu sendiri. Keandalan dapat diartikan sebagai kemampuan untuk memberikan layanan yang tepat sesuai waktu yang dijanjikan, serta bebas dari kesalahan (Iberahim 2016). Keandalan suatu mesin dapat juga diartikan sebagai terjaganya kualitas part dari mesin agar dapat beroperasi sesuai dengan fungsi yang diharapkan setiap waktu (Jay \& Barry 2014). Ada dua faktor yang berpengaruh terhadap keandalan dari vending machine. Pertama adalah konsistensi, menggambarkan bagaimana output dari vending machine tersebut selalu terstandar kapanpun mesin itu beroperasi. Kedua adalah dependability, menggambarkan bagaimana vending machine dapat selalu digunakan sesuai dengan ekspektasi customer (Yang \& Fang 2004).

\subsection{Refund system}

Kebijakan retur seringkali diberikan oleh pengecer dengan tujuan untuk meningkatkan pembelian (Greatorex \& Mitchell 1994). Hal ini didukung dengan penelitian Wood (2001) dan Wang (2009) yang menunjukkan bahwa kelonggaran yang diberikan pada konsumen untuk melakukan retur dapat meningkatkan penjualan. Namun di sisi lain, kelonggaran ini tidak terbukti akan meningkatkan frekuensi dari permintaan retur itu sendiri. Selain itu, kebijakan retur yang melibatkan faktor keuangan dan usaha memiliki kecenderungan untuk meningkatkan penjualan (Janakiraman et al., 2015).

\subsection{Responsiveness}

Responsiveness dapat diartikan sebagai kemampuan untuk merespon kebutuhan customer dengan tepat waktu dan sefleksibel mungkin (Iberahim 2016). Kemampuan ini pula yang dipercaya dibutuhkan oleh setiap organisasi guna meraih keunggulan bersaing (Reichhart \& Holweg 2007). Penanganan keluhan yang buruk mendorong customers untuk menyebarluaskan kekecewaannya 
kepada publik, sehingga hal ini tentunya dapat berdampak buruk pada citra perusahaan (Latif et al., 2010).

\subsection{Product Quality}

Kualitas produk didefinisikan sebagai karakteristik dari produk atau servis yang memenuhi fungsinya untuk memuaskan kebutuhan eksplisit maupun implisit konsumen (Kotler \& Armstrong 2012). Berkualitas atau tidaknya suatu produk merupakan suatu kesimpulan yang ditarik oleh pembeli. Kualitas produk dipengaruhi oleh dua faktor, yakni perceived product quality dan expected product quality (Razak, Nirwanto, dan Triatmanto 2016). Beberapa indikator yang membentuk kualitas produk secara utuh, yaitu: performa, fitur, keandalan, kesesuaian, ketangguhan, kemampuan dalam memberikan layanan, keindahan, dan persepsi pelanggan akan kualitas suatu produk/layanan (Kotler \& Keller 2012).

\subsection{Kelengkapan Produk}

Kelengkapan produk didefinisikan sebagai tersedianya produk sesuai dengan inti dari bisnis yang dijalankan. Di samping itu, faktor kecocokan dari jumlah, waktu, dan harga produk yang dijual turut serta mempengaruhi tingkat kelengkapan produk (Ma'ruf 2005)

Dua komponen yang membentuk kelengkapan produk adalah ragam dan ketersediaan barang. Beberapa parameter yang dapat digunakan untuk mengukur variabel kelengkapan produk diantaranya adalah: ragam, variasi, ketersediaan, dan merek (Raharjani 2005).

\section{Metodologi Penelitian}

\subsection{Lokasi dan Waktu Penelitian}

\subsubsection{Lokasi Penelitian}

Penelitian ini dilaksanakan di Bandara Halim Perdana Kusuma, Jakarta. Lokasi yang menjadi sasaran utama dalam penelitian adalah terminal keberangkatan dan terminal kedatangan. 
Dasar dari pemilihan lokasi penelitian di Bandara Halim Perdana Kusuma Jakarta yaitu:

1. Veranda Kencana memiliki vending machine di lokasi tersebut.

2. Vending machine lebih sering ditemui di tempat transportasi umum dengan arus pengunjung yang tinggi.

3. Adanya keterbatasan ruang dan waktu yang menjadi salah satu alasan pengunjung bandar udara untuk menggunakan vending machine.

\subsubsection{Waktu Penelitian}

Waktu yang dibutuhkan untuk melakukan penelitian ini kurang lebih dua bulan. Penelitian ini akan dimulai pada tanggal 11 Oktober 2017 hingga 25 November 2017.

\subsection{Metode Penelitian}

Metode penelitian yang digunakan adalah metode deskriptif. Pada penelitian ini, Penulis ingin menjabarkan data-data yang telah dikumpulkan di lapangan untuk melihat customer satisfaction dari PT Veranda Kencana.

\subsection{Populasi dan Sampel}

Populasi merupakan wilayah generalisasi yang terdiri atas objek atau subjek yang mempunyai kualitas dan karakteristik tertentu yang untuk kemudian dipelajari dan disimpulkan. Sedangkan, sampel diartikan sebagai bagian dari jumlah dan karakteristik yang dimiliki oleh populasi tersebut (Sugiyono 2006).

Teknik sampling yang digunakan pada penelitian ini adalah teknik simple random sampling. Teknik ini mendapatkan data secara acak tanpa memperhatikan kelas, usia serta jenis kelamin dari responden. Jumlah sampel yang digunakan adalah 50 orang yang pernah menggunakan vending machine di Bandara Halim Perdana Kusuma. 
Vol.01, No. 2, 2018

\subsection{Teknik Pengumpulan Data dan Instrumen Penelitian}

Teknik pengumpulan data dilakukan dengan survey. Adapun instrumen yang digunakan adalah berupa kuesioner. Kuesioner dalam penelitian ini menggunakan skala sikap model Likert yang telah disesuaikan dengan menampilkan 7 pilihan.

\subsection{Teknik Analisis Data}

Penelitian ini menggunakan teknik analisis data statistik deskriptif. Statistik deskriptif adalah statistik yang digunakan untuk menganalisis data dengan cara mendeskripsikan data yang terkumpul tanpa bermaksud membuat kesimpulan.

\section{Analisis Data}

\subsection{Machine Malfunction}

Tabel 4.1 Descriptive Statistics Machine Malfunction

Sumber: Penulis

\begin{tabular}{|c|c|c|c|c|}
\hline \multirow[b]{2}{*}{ Items } & \multicolumn{4}{|c|}{ Descriptive Statistics } \\
\hline & Min & Max & Mean & STDEV \\
\hline \multicolumn{5}{|l|}{ Machine Malfunction } \\
\hline Vending machine berfungsi dengan seharusnya & 3 & 7 & 5.74 & $\begin{array}{r}1.321872 \\
512\end{array}$ \\
\hline $\begin{array}{l}\text { Vending machine mengambil uang namun tidak } \\
\text { mengeluarkan barang yang dipilih }\end{array}$ & 1 & 7 & 6.38 & $\begin{array}{r}1.104536 \\
102\end{array}$ \\
\hline $\begin{array}{l}\text { Vending machine berulang kali menolak uang yang } \\
\text { dimasukkan }\end{array}$ & 1 & 7 & 4.72 & $\begin{array}{r}1.552351 \\
738\end{array}$ \\
\hline $\begin{array}{l}\text { Vending machine mengeluarkan barang yang salah } \\
\text { (tidak sesuai dengan apa yang dipilih) }\end{array}$ & 2 & 7 & 6.08 & $\begin{array}{r}1.352850 \\
354\end{array}$ \\
\hline Total & & & 5.73 & \\
\hline
\end{tabular}

Tabel 4.1 di atas menunjukkan bahwa nilai rata-rata total dari machine malfunction adalah sebesar 5,73. Setelah mengkonversikan skor ini ke 5-point 
Vol.01, No. 2, 2018

likert scale, angka akhir yang didapatkan adalah 4.15. Angka ini menunjukkan bahwa pelanggan puas dengan kinerja vending machine. Meskipun demikian, PT Veranda Kencana perlu memperhatikan perihal malfunction yang berkaitan dengan penolakan. Hal ini ditunjukkan dengan nilai rata-rata dari item tersebut, yang memiliki nilai paling rendah dibandingkan dengan item lainnya.

\subsection{Refund System}

Tabel 4.2 Descriptive Statistics Refund System

Sumber: Penulis

\begin{tabular}{|c|c|c|c|c|}
\hline & \multicolumn{4}{|c|}{ Descriptive Statistics } \\
\hline & Min & Max & Mean & STDEV \\
\hline Refund System & & & & \\
\hline $\begin{array}{l}\text { Kepuasan Anda terhadap cara yang ditawarkan untuk } \\
\text { memberikan keluhan }\end{array}$ & 3 & 7 & 5.28 & $\begin{array}{r}1.088717 \\
65\end{array}$ \\
\hline $\begin{array}{l}\text { Tata cara penukaran barang memakan usaha yang } \\
\text { besar }\end{array}$ & 3 & 7 & 5.7 & $\begin{array}{r}1.199489 \\
687\end{array}$ \\
\hline Barang yang kadaluarsa tidak dapat ditukar & 4 & 7 & 5.88 & $\begin{array}{r}1.136410 \\
389\end{array}$ \\
\hline Total & & & 5.62 & \\
\hline
\end{tabular}

Berdasarkan Tabel 4.2, dapat dilihat bahwa nilai rata-rata dari refund system PT Veranda Kencana menunjukkan angka 5.62. Setelah mengkonversikan skor ini ke 5-point likert scale, angka akhir yang didapatkan adalah 4.08. Dari angka tersebut, Penulis menyimpulkan bahwa pelanggan puas dengan refund system yang ada saat ini.

\subsection{Responsiveness to Complaints}

Tabel 4.3 Descriptive Statistics Responsiveness to Complaints Sumber: Penulis

\begin{tabular}{|l|l|l|l|l|}
\hline & \multicolumn{4}{|c|}{ Descriptive Statistics } \\
\hline & Min & Max & Mean & STDEV \\
\hline
\end{tabular}


Vol.01, No. 2, 2018

\begin{tabular}{|l|r|r|r|r|}
\hline Responsiveness to Complaints & & & & \\
\hline $\begin{array}{l}\text { Penyedia vending machine tidak merespon keluhan } \\
\text { yang diberikan }\end{array}$ & 4 & 7 & 5.88 & 1.154229 \\
\hline $\begin{array}{l}\text { Ketika terjadi masalah, saya tidak mendapatkan } \\
\text { penukaran barang seperti yang sudah dijanjikan }\end{array}$ & 4 & 7 & 6.18 & 768 \\
\hline Total & & & 6.03 & \\
\hline
\end{tabular}

Berdasarkan Tabel 4.3, nilai rata-rata yang diberikan oleh pelanggan PT Veranda Kencana berkaitan dengan respon perusahaan terhadap keluhan adalah 6.03. Setelah mengkonversikan skor ini ke 5-point likert scale, angka akhir yang didapatkan adalah 4.35. Angka ini menunjukkan bahwa respon perusahaan terhadap keluhan dari pelanggan dianggap memuaskan.

\subsection{Quality of Items}

Tabel 4.4 Descriptive Statistics Quality of Items

Sumber: Penulis

\begin{tabular}{|c|c|c|c|c|}
\hline & \multicolumn{4}{|c|}{ Descriptive Statistics } \\
\hline & Min & Max & Mean & STDEV \\
\hline Quality of Items & & & & \\
\hline $\begin{array}{l}\text { Produk yang ada di dalam vending machine } \\
\text { kadaluarsa }\end{array}$ & 5 & 7 & 6.3 & $\begin{array}{r}0.735402 \\
1529\end{array}$ \\
\hline Kualitas produk buruk & 3 & 7 & 5.9 & $\begin{array}{r}1.216384 \\
74\end{array}$ \\
\hline Total & & & 6.1 & \\
\hline
\end{tabular}

Tabel 4.4 di atas memperlihatkan nilai rata-rata yang didapatkan untuk menilai kualitas produk yang dijual PT Veranda Kencana adalah 6.1. Setelah mengkonversikan skor ini ke 5-point likert scale, angka akhir yang didapatkan adalah 4.4. Angka tersebut mengindikasikan bahwa pelanggan puas dengan kualitas barang-barang yang dijual oleh PT. Veranda Kencana. 
Vol.01, No. 2, 2018

\subsection{Kelengkapan Produk}

Tabel 4.5 Descriptive Statistics Kelengkapan Produk Sumber: Penulis

\begin{tabular}{|c|c|c|c|c|}
\hline & \multicolumn{4}{|c|}{ Descriptive Statistics } \\
\hline & Min & Max & Mean & STDEV \\
\hline \multicolumn{5}{|l|}{ Kelengkapan Produk } \\
\hline Barang yang diinginkan habis & 3 & 7 & 5.4 & $\begin{array}{r}1.324802 \\
642\end{array}$ \\
\hline Banyak item yang tidak ada di vending machine & 3 & 7 & 5.08 & $\begin{array}{r}1.139996 \\
42\end{array}$ \\
\hline Total & & & 5.24 & \\
\hline
\end{tabular}

Berdasarkan Tabel 4.5, terlihat bahwa dari segi kelengkapan produk, pelanggan PT Veranda Kencana sudah puas. Hal ini didukung dari nilai rata-rata dari kedua item yang bernilai 5.24. Setelah mengkonversikan skor ini ke 5-point likert scale, angka akhir yang didapatkan adalah 3.83.

Seperti yang dikemukakan sebelumnya, Jones dan Sasser (1995) mengemukakan bahwa terdapat perbedaan yang sangat signifikan terkait dengan perilaku satisfied customers dan completely satisfied customers. Berdasarkan hasil kuesioner, diketahui bahwa customer satisfaction yang dilihat dari kinerja vending machine, refund system, respon terhadap keluhan, kualitas barang, serta kelengkapan produk dari PT Veranda Kencana saat ini menunjukkan bahwa pengguna PT Veranda Kencana masih termasuk ke dalam kelompok "satisfied". Kelompok ini terdiri dari pelanggan dengan loyalitas yang relatif rendah, sehingga berpotensi untuk dengan mudah berpindah ke kompetitor.

\section{Kesimpulan dan Rekomendasi}

\subsection{Kesimpulan}


Vol.01, No. 2, 2018

Berdasarkan analisis data pada bab sebelumnya, dapat disimpulkan bahwa secara umum, pelanggan PT Veranda Kencana merasa puas terhadap layanan yang sudah diberikan. Hal tersebut tercermin dari nilai rata-rata untuk machine malfunction, refund system, responsiveness to complaints, quality of items, dan kelengkapan produk yang telah dikonversikan ke 5-point likert scale seperti pada penelitian Jones dan Sasser (1995).

Seperti yang sudah dijelaskan sebelumnya, sales performance turut dipengaruhi oleh customer satisfaction. Namun, pada kasus ini, penurunan sales di PT Veranda Kencana tetap terjadi meskipun hasil dari kuesioner menunjukkan bahwa pelanggan puas dengan kinerja vending machine, refund system, respon terhadap keluhan, kualitas barang, serta kelengkapan produk dari PT Veranda Kencana saat ini. Hal ini mungkin terjadi mengingat teori dari Jones dan Sasser yang menyimpulkan bahwa terdapat perbedaan level loyalitas antara satisfied customers dan completely satisfied customers. Pelanggan PT Veranda Kencana yang masih termasuk dalam kategori satisfied customers dapat menjadi salah satu penyebab mudahnya mereka untuk beralih ke kompetitor, sehingga perusahaan mengalami penurunan sales.

\subsection{Rekomendasi}

Berdasarkan analisis yang telah dilakukan, berikut ini merupakan rekomendasi untuk PT Veranda Kencana:

1. PT Veranda Kencana perlu mempertimbangkan untuk melakukan penyempurnaan terkait variabel machine malfunction, refund management, responsiveness to complaints, quality of items, dan kelengkapan produk dari layanan vending machine perusahaan.

2. PT Veranda Kencana perlu melakukan penelitian lebih lanjut untuk mengetahui variabel-variabel lain yang dapat mempengaruhi penurunan revenue selain dari customer satisfaction. 
Vol.01, No. 2, 2018

3. PT Veranda Kencana perlu melakukan penelitian berkala untuk mengetahui customer satisfaction dari pelanggan karena loyalitas dari pelanggan belum sepenuhnya terbangun. 


\section{DAFTAR PUSTAKA}

Bernardes, E. S. \& Hanna, M. D. (2009), “A Theoretical Review of Flexibility, Agility and Responsiveness in the Operations Management Literature: Toward a Conceptual Definition of Customer Responsiveness", International Journal of Operations and Production Management, Vol. 29, No.1: 30-53.

Go' mez, M., McLaughlin, E., dan Wittink, D. (2004), "Customer Satisfaction and Retail Sales Performance: An Empirical Investigation", Journal of Retailing, Vol. 80, No.4: 265-278.

Greatorex, Mike \& Vincent W. Mitchell. (1994), “Modelling Consumer Risk Reduction Preferences from Perceived Loss Data", Journal of Economic Psychology, Vol. 15, No.4: 669-685.

Iberahim, H, dkk. (2016), "Customer Satisfaction on Reliability and Responsiveness of Self Service Technology for Retail Banking Service", Procedia Economics and Finance, Vol. 37, No.3: 13-20.

Intelligent Vending Machines Market Analysis By Type (Hot Drinks, Snacks, Packaged Drinks), By Application (QSR, Shopping Malls, \& Retail Stores, Offices, Public Transport), By Region, And Segment Forecast, 2018-2025, Grand View Research, 2016.

Janakiraman, Holly A. Syrdal, dan Ryan Freling. (2016), "The Effect of Return Policy Leniency on Consumer Purchase and Return Decisions: A Metaanalytic Review", Journal of Retailing, Vol. 92, No.2: 226-235.

Jay, H. \& Barry R. (2014), Operation Management: Sustainability and Supply Chain Management 11th Edition, Pearson.

Kotler, P \& Armstrong, G. (2012), Principle of Marketing 14th Edition, Prentice Hall, New Jersey.

Kotler, P \& Keller, K. L. (2012), Marketing Management 14th Edition, Prentice Hall, New Jersey. 
Latif, dkk. (2010), Improving Accessibility and Responsiveness in a Complaints Management System, E-Leader Singapore.

Lee, Dong Hwan. (2003), “Consumers' Experiences, Opinions, Attitudes, Satisfaction, Dissatisfaction, and Complaining Behavior with Vending Machines", Journal of Consumer Satisfaction, Dissatisfaction, and Complaining Behavior, Vol. 16: 178-197.

Ma'ruf, Hendri. (2005), Pemasaran Retail, Gramedia Pustaka Utama, Jakarta. Raharjani, Jeni. (2005), “Analisis Faktor-Faktor yang Mempengaruhi Keputusan Pemilihan Pasar Swalayan Sebagai Tempat Berbelanja (Studi Kasus Pada Pasar Swalayan di Kawasan Seputar Simpang Lima Semarang)", Jurnal Studi Manajemen \& Organisasi, Vol. 2, No. 1: 1-15. Razak, Ismail, Nazief Nirwanto, dan Boge Triatmanto. (2016), "The Impact of Product Quality and Price on Customer Satisfaction with the Mediator of Customer Value", Journal of Marketing and Consumer Research, Vol. 30: 59-68.

Reichhart, A. \& Holweg, M. (2007), “Creating the Customer-Responsive Supply Chain: A Reconciliation of Concepts", International Journal of Production Planning \& Control, Vol. 27, No. 11: 1144-1172.

Rust, R., Zahorik, A., dan Keiningham, T. (1995), "Return on Quality (ROQ):

Making Service Quality Financially Accountable", Journal of Marketing, Vol. 59 (April 1995): 58-70.

Shen, X. X., Tan, K. C., \& Xie, M. (2000), “An Integrated Approach to Innovative Product Development Using Kano's Model and QFD", European Journal of Innovation Management, Vol. 3, No.2: 91-99.

Sugiyono. (2006), Metode Penelitian Kuantitatif, Kualitatif dan $R \& D$, Alfabeta, Bandung.

The Harvard Business Review Website, https://hbr.org/1995/11/why-satisfiedcustomers-defect, (27 Maret 2018). 
Vol.01, No. 2, 2018

Wang, Xianghong. (2009), "Retail Return Policy, Endowment Effect and Assumption Propensity: An Experimental Study", The BE Journal of Economic Analysis \& Policy, Vol. 9, No.1: 1-29.

Wood, Stacy L. (2001), “Remote Purchase Environments: The Influence of Return Policy Leniency on Two-Stage Decision Processes", Journal of Marketing Research, Vol. 38, No.2: 157-169.

www.trendmesin.com, http://www.trendmesin.com/2015/08/vending-machinemesin-penjual-otomatis.html, (10 Maret 2018).

Yang, Z., \& Fang, X. (2004), “Online Service Quality Dimensions and Their Relationships with Satisfaction: A Content Analysis of Customer Reviews of Securities Brokerage Services", International Journal of Service Industry Management, Vol. 15, No.3: 302-326. 


\section{LAMPIRAN}

\section{Lampiran 1. Daftar Pertanyaan}

\section{Machine Malfunction}

- Vending Machine berfungsi dengan seharusnya (Tidak Pernah - Selalu)

- Vending Machine mengambil uang namun tidak mengeluarkan barang yang dipilih (Selalu - Tidak Pernah)

- Vending Machine berulang kali menolak uang yang dimasukan ? (Selalu - Tidak Pernah)

- Vending Machine mengeluarkan barang yang salah (tidak sesuai dengan apa yang dipilih) (Selalu - Tidak Pernah)

\section{Refund System}

- Kepuasan Anda terhadap cara yang ditawarkan untuk memberikan keluhan (Sangat tidak memuaskan - Memuaskan)

- Tata cara penukaran barang memakan usaha yang besar (Selalu - Tidak pernah)

- Barang yang kadaluarsa tidak dapat ditukar (Selalu - Tidak pernah)

\section{Responsiveness to Complaints}

- Penyedia vending machine tidak merespon keluhan yang diberikan (Selalu Tidak pernah)

- Ketika terjadi masalah, saya tidak mendapatkan penukaran barang seperti yang sudah dijanjikan (Selalu - Tidak pernah)

\section{Quality of Items}

- Produk yang ada di dalam vending machine kadaluarsa (Selalu - Tidak pernah)

- Kualitas produk buruk (Selalu - Tidak pernah)

\section{Kelengkapan Produk}

- Barang yang diinginkan habis (Selalu - Tidak pernah)

- Banyak item yang tidak ada di vending machine (Selalu - Tidak pernah) 